\title{
Expression of Neural RGS-R7 and G $\beta 5$ Proteins in Response to Acute and Chronic Morphine
}

\author{
Almudena López-Fando', María Rodríguez-Muñoz', Pilar Sánchez-Blázquez' and Javier Garzón*,I \\ 'Neurofarmacología, Instituto de Neurobiología Santiago Ramón y Cajal, CSIC, Madrid, Spain
}

\begin{abstract}
The R7 subfamily of regulators of G-protein signaling (RGS) proteins (RGS6, RGS7, RGS9-2, and RGSI I), and its binding protein G $\beta 5$, are found in neural structures of mouse brain. A single intracerebroventricular priming dose of $10 \mathrm{nmol}$ morphine gave rise to acute tolerance to the analgesic effects of successive identical test doses of the opioid. At $2 \mathrm{~h}$ after administering the acute opioid, RGS7 mRNA levels in the striatum plus those of RGS9-2 in the striatum and thalamus were increased, whereas RGS9-2 and RGSII mRNA were reduced in the cortex. Similar but attenuated RGS-R7 mRNA changes persisted $24 \mathrm{~h}$ after acute morphine administration. No changes in G $\beta 5$ mRNA levels were observed. At 2 days after commencing sustained morphine treatment, the levels of mRNA for RGS7, RGS9-2, RGSII, and G $\beta 5$ increased in most of the brain structures studied (striatum, thalamus, periaqueductal gray matter (PAG), and cortex). In these morphine tolerant-dependent mice, the greater changes were found for RGS9-2 in the thalamus (>500\%) and PAG (>200\%). In post-dependent mice, the increases in RGS-R7 and G $\beta 5$ mRNA still persisted in the PAG and striatum at 8 and 16 days after starting the chronic opioid treatment. The raised mRNA levels promoted by chronic, but not by acute, morphine, were accompanied by increases in the encoded proteins. This is probably a result of the costabilization of the RGS-R7 and G $\beta 5$ proteins forming heterodimers. Opioidinduced adaptations of RGS-R7 and G $\beta 5$ genes may regulate the severity of morphine-induced tolerance/dependence and the duration of the post-dependent period, helping to recover the normal response.

Neuropsychopharmacology (2005) 30, 99-I I0, advance online publication, 16 June 2004; doi: I0. I038/sj.npp. I 3005 I 5
\end{abstract}

Keywords: G-proteins; regulator of G-protein signaling; R7 subfamily of RGS proteins; G $\beta 5$ protein; morphine; acute tolerance; opioid tolerance

\section{INTRODUCTION}

The regulators of G-protein signaling (RGS) proteins are GTPase-activating proteins (GAP) whose target are the $\alpha$ subunits of the heterotrimeric Gi, Go, Gz, Gt, and Gq proteins. All contain the so-called RGS box. This is a conserved domain of approximately 130 amino-acid residues that binds the G $\alpha$ GDP.P transition state of activated subunits and accelerates their intrinsic GTPase activity. The mammalian RGS proteins, of which there are about 20 , are grouped into five subfamilies, Rz, R4, R7, R12, and Ra, according to structural and genetic similarities (Hepler, 1999; Ross and Wilkie, 2000). In situ mRNA hybridization (Gold et al, 1997; Shuey et al, 1998), Northern blot analyses (Snow et al, 1998; Saitoh et al, 1999), and RT-PCR studies (Sánchez-Blázquez et al, 2003; Garzón et al, 2004) have

\footnotetext{
*Correspondence: J Garzón, Neurofarmacología, Instituto Cajal, Consejo Superior de Investigaciones Científicas, Avd Doctor Arce, 37, Madrid E-28002, Spain, Tel: + 3491585 4733, Fax: + 34 9I 585 4754, E-mail: jgarzon@cajal.csic.es

Received 4 February 2004; revised 22 April 2004; accepted 18 May 2004

Online publication: 19 May 2004 at http://www.acnp.org/citations/ Npp05190404050/default.pdf
}

demonstrated the presence of the mRNA in the CNS coding for the majority of the RGS and of their associated proteins.

There is increasing evidence supporting the involvement of RGS proteins in opioid effects. This has been documented in both in vitro (Potenza et al, 1999; Rahman et al, 1999) and in vivo studies (Garzón et al, 2001, 2003, 2004; SánchezBlázquez et al, 2003; Zachariou et al, 2003). The members of the RGS-R7 subfamily in CNS - RGS6, RGS7, RGS9-2, and RGS11 - mostly associate with cell membranes (Rose et al, 2000; Zhang and Simonds, 2000; Garzón et al, 2003; Sánchez-Blázquez et al, 2003). Their sequences contain the G-protein $\gamma$-subunit-like (GGL) domain (for a review see Hollinger and Hepler, 2002) that binds to the $G \beta 5$ protein but not to the other G $\beta$ subunits (Snow et al, 1998; Hepler, 1999; Zhang and Simonds, 2000). In nervous tissue, the RGS-R7 and G $\beta 5$ proteins are always found as dimers, indicating this association is required for their GAP function on the corresponding G $\alpha$ GTP subunits (Snow et al, 1998; Zhang and Simonds, 2000; Sánchez-Blázquez et al, 2003). The RGS-R7 proteins all reduce the amplitude and duration of $\mu$-opioid receptor-mediated effects (Garzón et al, 2001, 2003; Sánchez-Blázquez et al, 2003), whereas they show notable differences in their quality of action on delta agonist-mediated effects (Garzón et al, 2003). An observation of interest is that RGS-R7 and $\mathrm{G} \beta 5$ proteins 
facilitate agonist tachyphylaxis and acute tolerance at $\mu$ opioid receptors. These regulatory processes might involve the sequestration of agonist-segregated $\mathrm{G} \alpha$ subunits by RGS-R7/G $\beta 5$ heterodimers (Garzón et al, 2001, 2003; Sánchez-Blázquez et al, 2003).

The RGS genes show rapid changes in the expression following many kinds of experimental or physiological stimulus. The RGS-R4 subfamily shows remarkable plasticity. RGS4 is regulated differentially in hypothalamic nuclei by stress and glucocorticoids (Ni et al, 1999). It shows morphine-insensitive upregulation in a model of neuropathic pain (Garnier et al, 2003) and is reduced in schizophrenia (Mirnics et al, 2001). The acute or repeated administration of amphetamine promotes selective changes in striatal RGS-R4 mRNA levels (Burchett et al, 1998, 1999). Agonists and antagonists at D1 and D2 dopamine receptors also bring about changes in the level of this RGS4 mRNA (Robinet et al, 2001a,b; Geurts et al, 2002; Taymans et al, 2003). In rat brain, RGS-R4 and RGS-R7 genes are also responsive to acute and chronic electroconvulsive seizures (Gold et al, 1997, 2002). Acute morphine and cocaine decrease RGS4 in nucleus accumbens, whereas their chronic administration increases its levels (Bishop et al, 2002). Chronic cocaine also increases RGS9-2 in the nucleus accumbens (Rahman et al, 2003). Chronic opioids increase the expression of RGS4 mRNA in PC12 cells expressing opioid receptors (Nakagawa et al, 2001). In the rat locus coeruleus, RGS-R4 and RGS-R7 mRNA contents show no variation during chronic morphine treatment, but RGS2 and RGS4 mRNA increase after precipitating opioid withdrawal (Gold et al, 2003). Acute morphine increases RGS9-2 in the nucleus accumbens and the dorsal horn of the spinal cord, whereas in morphine tolerant-dependent mice this protein decreases in these structures (Zachariou et al, 2003).

This study examines the distribution of the mRNA and the expression levels of the RGS-R7 members present in mouse brain. Our previous studies indicate that the entire RGS-R7 subfamily plays an important role in regulating signals originated at $\mu$-opioid receptors (Garzón et al, 2001, 2003; Sánchez-Blázquez et al, 2003). Therefore, we also analyzed the plasticity of the RGS-R7 members and of their partner protein $\mathrm{G} \beta 5$ in response to acute and chronic morphine, both in the periaqueductal gray matter (PAG) (an area involved in the analgesic effects of opioids administered by the intracerebroventricular (i.c.v.) route) and other structures of the mouse brain. The same was examined in post-dependent mice.

\section{MATERIALS AND METHODS}

\section{Animals and Evaluation of Antinociception}

Male albino mice CD-1 (Charles River) weighing 22-25 $g$ were housed and used strictly in accordance with the guidelines of the European Community for the Care and Use of Laboratory Animals (Council Directive 86/609/EEC). The response of the animals to nociceptive stimuli was determined by the warm water $\left(52^{\circ} \mathrm{C}\right)$ tail-flick test. Antinociception was expressed as a percentage of the maximum possible effect $(\mathrm{MPE}=100 \times($ test latencybaseline latency)/(cutoff time $\{10 \mathrm{~s}\}$-baseline latency)).

\section{Production of Acute Tolerance to Morphine}

Animals were lightly anesthetized with ether, and $10 \mathrm{nmol}$ morphine in $4 \mu \mathrm{l}$ (priming dose) (Garzón et al, 2001) were i.c.v. injected into the right lateral ventricle as described previously (Sánchez-Blázquez et al, 1995). Controls were given saline instead. The development of acute tolerance was monitored when the priming dose had no effect on baseline latencies. Thus, $24 \mathrm{~h}$ later an identical dose of morphine (test dose) was i.c.v. injected into all mice of both the treatment and control groups. Acute tolerance assays were performed when the morphine reached its peak effect (after $30 \mathrm{~min}$ ). Following the test dose, the mice were killed by decapitation at different intervals and the brain structures to be studied were obtained.

\section{Induction and Assessment of Tolerance/Physical Dependence on Chronic Morphine Treatment}

The mice were subcutaneously (s.c.) implanted with $10 \mathrm{ml} /$ $\mathrm{kg}$ body weight of a suspension containing $50 \%$ saline $(0.9 \%$ $\mathrm{NaCl}$ in distilled water), $42.5 \%$ mineral oil (Sigma 400-5), $7.5 \%$ mannide monooleate (Sigma M-8546), and $0.1 \mathrm{~g} / \mathrm{ml}$ morphine base (adapted from Sánchez-Blázquez et al, 1997). The development of tolerance was monitored by measuring the analgesic response to a single i.c.v. dose of $10 \mathrm{nmol}$ morphine. In mice not previously exposed to the opioid, this produced an effect of about $80 \% \mathrm{MPE}$ in the tail-flick test. Physical dependence was evaluated by precipitating a withdrawal syndrome with $1 \mathrm{mg} / \mathrm{kg}$ of s.c. naloxone. Groups of three mice were placed in acryl-glass boxes $(28 \mathrm{~cm} \times 28 \mathrm{~cm} \times 40 \mathrm{~cm})$. The number of jumps they made were recorded over the following $10 \mathrm{~min}$ (SánchezBlázquez et al, 1997). The mice were killed by decapitation at different intervals after pellet implantation and brain structures were collected.

\section{Detection of RGS-R7 and G $\beta 5$ Proteins in Mouse Brain: Electrophoresis and Immunoblotting}

The neural structures were procesed to obtain the synaptosomally enriched P2 fractions (Garzón et al, 2002). The brain structures required for obtaining the sought signals were pooled. Typically, three cerebral cortices and striata, five thalamus and PAG. SDS-solubilized P2 membranes were subsequently resolved by SDS/polyacrylamide gel electrophoresis (PAGE) in $8 \mathrm{~cm} \times 11 \mathrm{~cm} \times 1.5 \mathrm{~cm}$ gel slabs (7-14\% total acrylamide concentration $/ 2.6 \%$ bisacrylamide crosslinker concentration). The separated proteins were then transferred onto $0.45 \mu \mathrm{m}$ polyvinylidene difluoride membranes (Amersham Biosciences, RPN 303F). Polyclonal anti-RGS7 (SC8139), anti-RGS9 (SC8143), antiRGS11 (SC9724) 1:500 (Santa Cruz Biotechnology, Inc., Santa Cruz, CA, USA) and anti-G $\beta 5$ subunit (AB1648, Chemicon Europe Ltd, Hampshire, UK) were diluted in Tris-buffered saline- $0.05 \%$ Tween-20 (TTBS) and incubated with the transfer membranes at $6^{\circ} \mathrm{C}$ for 12 or $24 \mathrm{~h}$. The SC antibodies (raised in goat) were detected with donkey antigoat IgG horseradish peroxidase-conjugated antiserum (Santa Cruz Biotechnology, SC2020). The G $\beta 5$ antibody was detected with a goat anti-rabbit IgG $(\mathrm{H}+\mathrm{L})$ horseradish peroxidase-conjugated antiserum (BioRad, \#170-6515). 
Secondary antisera were diluted $1: 3000$ in TTBS, incubated for $2 \mathrm{~h}$, and revealed with DAB substrate solution. Immunoblots were visualized with a ChemiImager IS-5500 (Alpha Innotech, San Leandro, CA) and analyzed by densitometry (AlphaEase v3.2.2). For every control neural structure and antibody used in the study, a linear relationship between the amount of protein-typically 20, 40, 60 and for some structures with weaker signals, also $80 \mu \mathrm{g}$ protein/lane - and the intensity of the immunosignal was observed. Evaluation of the morphine-induced changes in RGS-R7/G $\beta 5$ immunoreactivity was performed on signals inside this linear range. The data are expressed as the mean $\pm S E M$ from at least three independent determinations.

\section{Analysis of RGS-R7 and G/5 mRNAs (RT-PCR)}

RT-PCR is the most sensitive technique for mRNA detection and quantization currently available. The end point relative RT-PCR was used to measure changes in expression levels comparing transcript abundance across multiple samples using a coamplified internal control for sample normalization. Total RNA was harvested from mouse brain structures using a single-step procedure (Ultraspec RNA isolation system, Biotecx Laboratories, Houston, TX, USA) based on the formation of RNA complexes with guanidium molecules, followed by isopropanol precipitation. The pellet was washed in $75 \%$ ethanol, dried, resuspended in $40 \mu \mathrm{l}$ RNA storage solution (Ambion, Austin, TX, USA), and stored at $-80^{\circ} \mathrm{C}$ until analysis. RNA yield was determinated using UV spectrometry $(260 \mathrm{~nm})$. This procedure gives RNA free of DNA contamination and ready for RT-PCR without additional tratment with DNase (maker specifications). This was confirmed in routine assays with PCR performed without the previous RT step. For every neural structure analyzed, $2 \mu \mathrm{g}$ of total RNA were reverse transcribed using the RT-PCR First Strand Synthesis Kit (RevertAid, MBI FERMENTAS) with oligo (deoxythymidine) priming as described previously (Sánchez-Blázquez et al, 2003). cDNA synthesis was performed at $42^{\circ} \mathrm{C}$ for $60 \mathrm{~min}$. The template for the PCR reaction was $125 \mathrm{ng}$ (RGS6), $25 \mathrm{ng}$ (RGS7), $100 \mathrm{ng}$ (RGS9-2 and RGS11) cDNA in a total volume of $50 \mu \mathrm{l}$ of buffer solution containing $10 \mathrm{mM}$ Tris- $\mathrm{HCl}$ ( $\mathrm{pH} 8.3$ ), $50 \mathrm{mM} \mathrm{KCl}, 1.5 \mathrm{mM} \mathrm{MgCl}_{2}, 125 \mu \mathrm{M}$ of each dNTP, $0.5 \mu \mathrm{M}$ of each primer, and $1 \mathrm{U}$ of SuperTaq thermostable DNA polymerase (Biotools, Spain).

The cDNA primers (Sigma-Genosys, Cambridge, UK) directed towards the RGS6 murine gene (AF061933) were forward 5'-GCGTTGGGGCTTCTCTTTTGATGA-3' (sense), corresponding to base pairs $804-827$ and reverse $5^{\prime}$ CCGCCAGCGACTTTCCCTTCTT-3' (antisense), corresponding to base pairs 1174-1195 (designed to yield a band size of $392 \mathrm{bp}$ ). Those directed towards the murine gene RGS7 (AF011360) were forward 5'-CCGAGGAGGGCA GATTGAT-3', corresponding to base pairs 123-141, and reverse 5'-GGGCAGCCATTAGCGTTCC-3', corresponding to base pairs $420-438$, in order to yield a band of $316 \mathrm{bp}$. Those towards the murine cerebral gene RGS9-2 (AF125046) were designed in a gene region that differs from the retinal gene RGS9-1 (AF011358). The secuences were: forward 5'-GTAGCCAACTTTTTCCAGAT-3' (sense), corresponding to base pairs 2013-2032, and reverse
5'-GGTGACCCTTTTATTGTTTT-3' (antisense), corresponding to base pairs 2413-2432 (in order to yield an expected band size of $420 \mathrm{bp}$ ). Those directed towards murine RGS11 (AF061934) were forward 5'-AGCGGCGGAAGGGAGACA GAAT- $3^{\prime}$, corresponding to base pairs $440-461$, and reverse 5'-CTCCTCACATGCCTCCCAGAAGC-3', corresponding to base pairs 908-930, designed to yield a segment of $491 \mathrm{bp}$. The cDNA primers (Sigma-Genosys Ltd, Cambridge, UK) directed towards the G $\beta 5$ murine gene (L34290) were forward 5'-GGCCGCCAAGAAGAAGT-3' (sense), corresponding to base pairs 456-472, and reverse $5^{\prime}$-AGGCGC CAAATATGATGCTC-3' (antisense), corresponding to base pairs 870-889 (designed to yield a band size of $434 \mathrm{bp}$ ).

Quantitative PCR amplified the RGS genes simultaneously with a sequence of the housekeeping gene for glyceraldehyde 3-phosphate dehydrogenase (GAPDH) that served as an internal control. The primer set directed towards the GAPDH murine gene (M32599) included 5'-ATCAC CATCTTCCAGGAGC-3' (sense), corresponding to base pairs 260-278, and 5'-ATCACAAACATGGGGGCATCGG-3' (antisense), corresponding to base pairs 417-438, which yielded a band of $179 \mathrm{bp}$. The GAPDH PCR products were matched with those of the RGS-R7 subfamily using GAPDH competimers (primers identical in sequence to the functional GAPDH primers but which were blocked at their $3^{\prime}$ end and could not, therefore, be extended by PCR). GAPDH competimers and primers were mixed at various ratios of $1: 0.75$ (RGS6), 1:1 (RGS7), 1:1.5 (RGS9-2), and $1: 2$ (RGS11). For each neural structure studied, the number of cycles was selected to give RGS-R7 amplimers in the linear phase of the PCR reaction.

In all, 31 amplification cycles were performed using thinwalled $0.2 \mathrm{ml}$ PCR tubes (Ambion) in a DNA Mastercycler (Eppendorf AG, Hamburg, Germany) according to the following protocol: one cycle of $94^{\circ} \mathrm{C}(1 \mathrm{~min})$ followed by 30 cycles of $94^{\circ} \mathrm{C}(20 \mathrm{~s})$ and $60^{\circ} \mathrm{C}(30 \mathrm{~s})$. A final $3 \mathrm{~min}$ incubation step was performed at $72^{\circ} \mathrm{C}$. Equal volumes $(15 \mu \mathrm{l})$ of PCR products were resolved in $2.5 \%$ agarose ethidium-bromide-stained gels with $80-1000$ bp PCR markers (Biotools). The relationship between the studied RGSR7 gene and GAPDH was calculated in terms of the relative level of expression. Fluorescent bands were visualized with UV light in a ChemiImager IS-5500 (Alpha Innotech, San Leandro, CA) and analyzed by densitometry (AlphaEase v3.2.2). The optical density of each band was compared with the respective GAPDH band after discarding the background. All experiments were repeated at least three times.

\section{Statistical Analysis of the Results}

The data collected were examined by analysis of variance (ANOVA) followed by the Student-Newman-Keuls test (SigmaStat, SPSS Science Software, Erkrath, Germany). The level of significance was set at $p<0.05$.

\section{RESULTS}

\section{Regional Localization of RGS-R7 Subfamily mRNA in Mouse Brain}

RT-PCR assays showed amplification of the predicted sequences of RGS-R7 proteins in all the neural areas 
evaluated. The data showed some region-specific patterns. Intense RGS6 mRNA signals were found in the spinal cord and pons-medulla. Weaker signals were seen for the cerebellum. RGS7 mRNA showed a more uniform distribution with highest levels in the cerebellum, followed by the hypothalamus, spinal cord, and thalamus. RGS9-2 mRNA was present in large amounts in the striatum, followed by the PAG and thalamus. The other CNS regions showed about one-third of the striatal mRNA content. RGS11 mRNA showed marked differences in distribution throughout the CNS. The strongest signals were observed in the hypothalamus and PAG, and the faintest for the striatum, cerebellum, and spinal cord (Figures 1 and 2). The G $\beta 5$ mRNA content was similar for all CNS structures, with the exception of the hypothalamus that showed the highest levels. These results have been reported before (SánchezBlázquez et al, 2003).

\section{Expression of RGS-R7 and of G $\beta 5$ Genes During the Development of Acute Tolerance to Morphine}

The i.c.v. injection of $10 \mathrm{nmol}$ morphine produced, at its peak (30 min after injection), an analgesic effect of about $80 \%$ of the MPE allotted for this test (cutoff time of $10 \mathrm{~s}$ ). A remnant effect of less than 20\% MPE was observed $2 \mathrm{~h}$ after the injection (Figure 3a). After $24 \mathrm{~h}$, however, no influence on the base line response of these animals could be detected. The threshold dose necessary to produce acute tolerance to morphine is about three to four times greater than that required for producing detectable analgesia (Huidobro et al, 1976). This interesting phenomenon appears within hours of agonist administration and lasts 2-3 days (Huidobro-Toro and Way, 1978; Garzón et al, 2002) (Figure 3b). The mRNA content was determined at 2 and $24 \mathrm{~h}$ intervals after the injection of this dose of morphine. After $2 \mathrm{~h}$, RGS7 mRNA slightly but significantly increased in the striatum (about 28\%), whereas that of RGS9-2 increased some $50 \%$ in this structure and some $130 \%$ in the thalamus. On the contrary, in cerebral cortex, RGS9-2 and RGS11 mRNA levels decreased by 27 and 50\%, respectively. After $24 \mathrm{~h}$, the changes observed at $2 \mathrm{~h}$ were absent or showed a tendency to diminish. No significant changes were observed for G $\beta 5$ mRNAs levels (Figure 4).

The antibodies directed to RGS-R7 and G $\beta 5$ proteins had been characterized previously (Garzón et al, 2001, 2003; Sánchez-Blázquez et al, 2003). In mouse CNS, the antibodies directed towards RGS-R7 and G $\beta 5$ proteins bind proteins of the size expected (about $55 \mathrm{kDa}$ for RGS7, $75 \mathrm{kDa}$ for RGS92, $50 \mathrm{kDa}$ for RGS11, and $39 \mathrm{kDa}$ for $\mathrm{G} \beta 5$; Figure 5). They selectively detect the reductions brought about by the antisense oligonucleotides directed to RGS-R7/G $\beta 5$ mRNA (Garzón et al, 2001, 2003; Sánchez-Blázquez et al, 2003). Moreover, the RGS-R7 antibodies proved effective in immunoprecipitating $\mathrm{G} \alpha$ subunits from CNS synaptosomal membranes and co-precipitated the G $\beta 5$ protein that associates selectively with this subfamily of RGS proteins (Sánchez-Blázquez et al, 2003). Figure 5 shows representative Western blots of the cerebral cortex at $24 \mathrm{~h}$ postmorphine. Our data demonstrate that $24 \mathrm{~h}$ after administering morphine, the levels of RGS7, RGS9-2, RGS11, and G $\beta 5$ proteins showed no significant changes
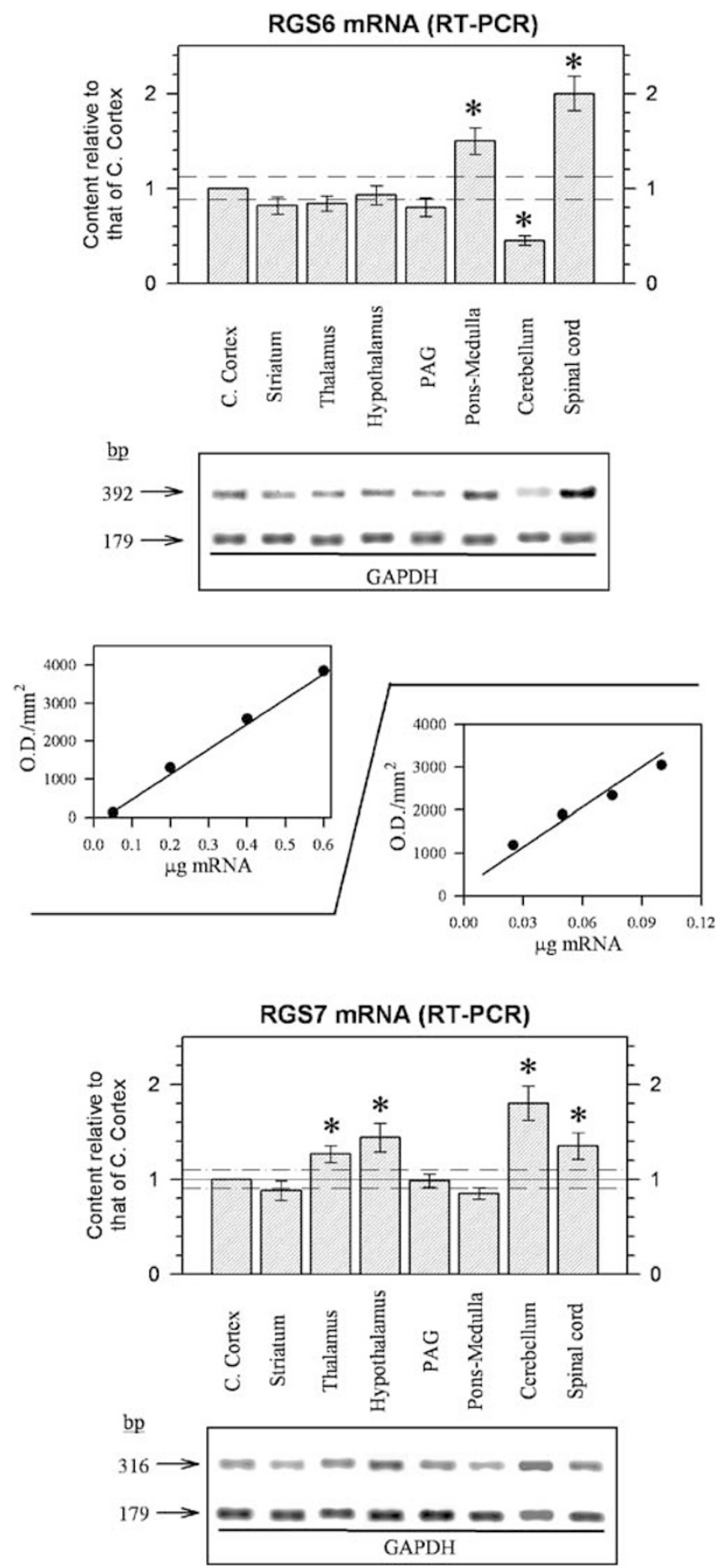

Figure I Detection of RGS6 and RGS7 mRNA in mouse brain. RT-PCR of RGS6 and RGS7 mRNA in different neural structures. The amplified products were 392 and 316 bp long for RGS6 and RGS7, respectively. A linear relationship was obtained for a range of micrograms of extracted RNA and the amplified 392 and 316 bp products. The signals associated to these RGS mRNA were normalized to those obtained by amplification of a segment of $179 \mathrm{bp}$ GAPDH - internal standard. Each data point shown is the mean value of three determinations (each performed in triplicate) performed on pooled reverse-transcribed RNA from eight to 10 mice. *Significantly different from the mRNA levels observed for cerebral cortex-arbitrary value of I. ANOVA followed by Student-NewmanKeuls test; $p<0.05$. 

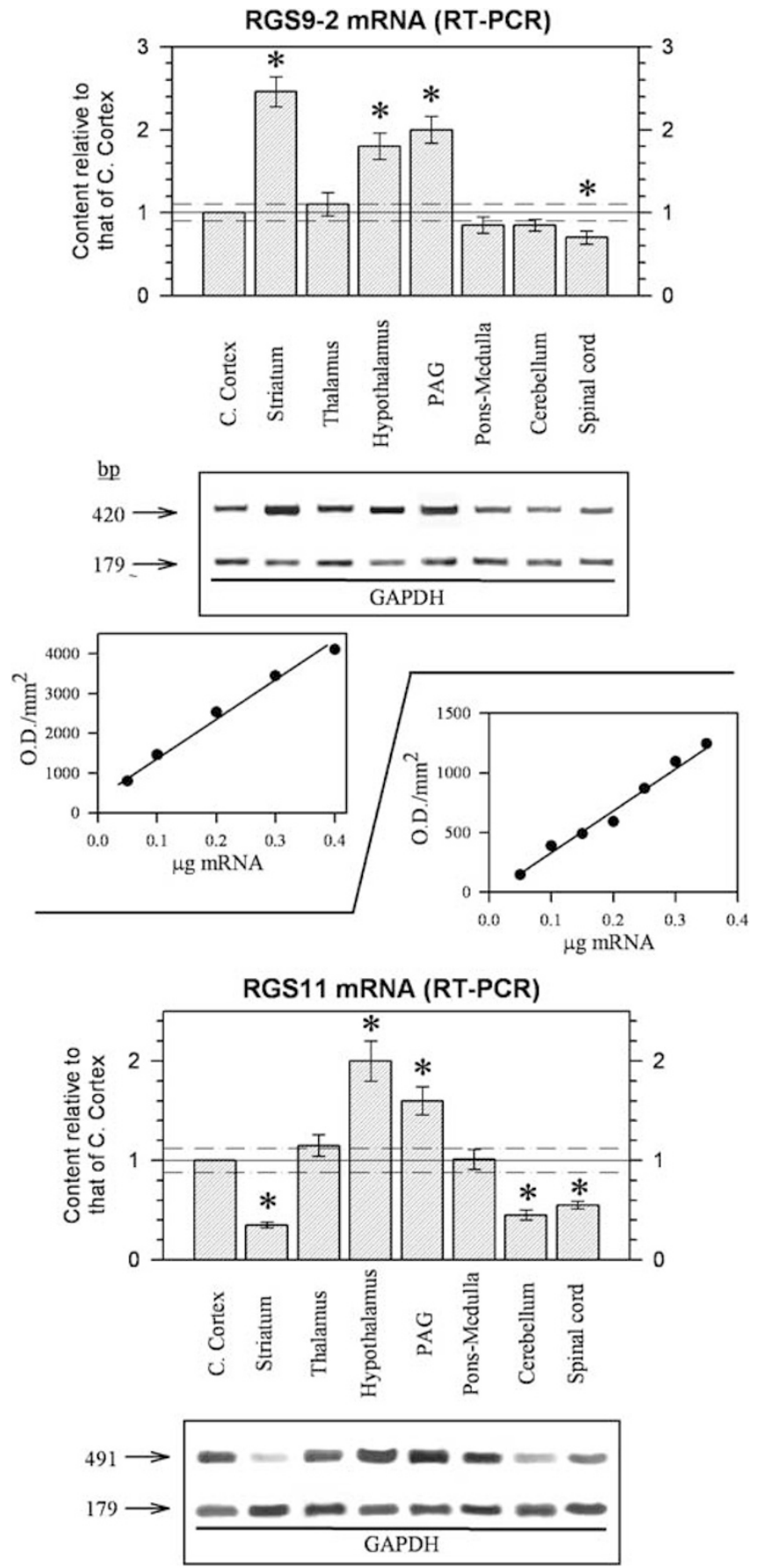

Figure 2 Detection of RGS9-2 and RGSI I mRNA in mouse brain. RTPCR of RGS9-2 and RGSII mRNA in different neural structures. The amplified products were 420 bp long and 49 I bp for RGS9-2 and RGSI I, respectively. A linear relationship was obtained for a range of micrograms of extracted RNA and the amplified products. Details as in the legend to Figure 1.

in the neural areas studied (RGS6 protein levels were not evaluated since no antibody is currently available).

RGS-R7 and G $\beta 5$ mRNA and Protein Contents in Brain Areas of Morphine Tolerant- and Post-Dependent Mice

Mice were s.c. implanted with the oily morphine pellet. Within the first hour, the analgesic response of the mice
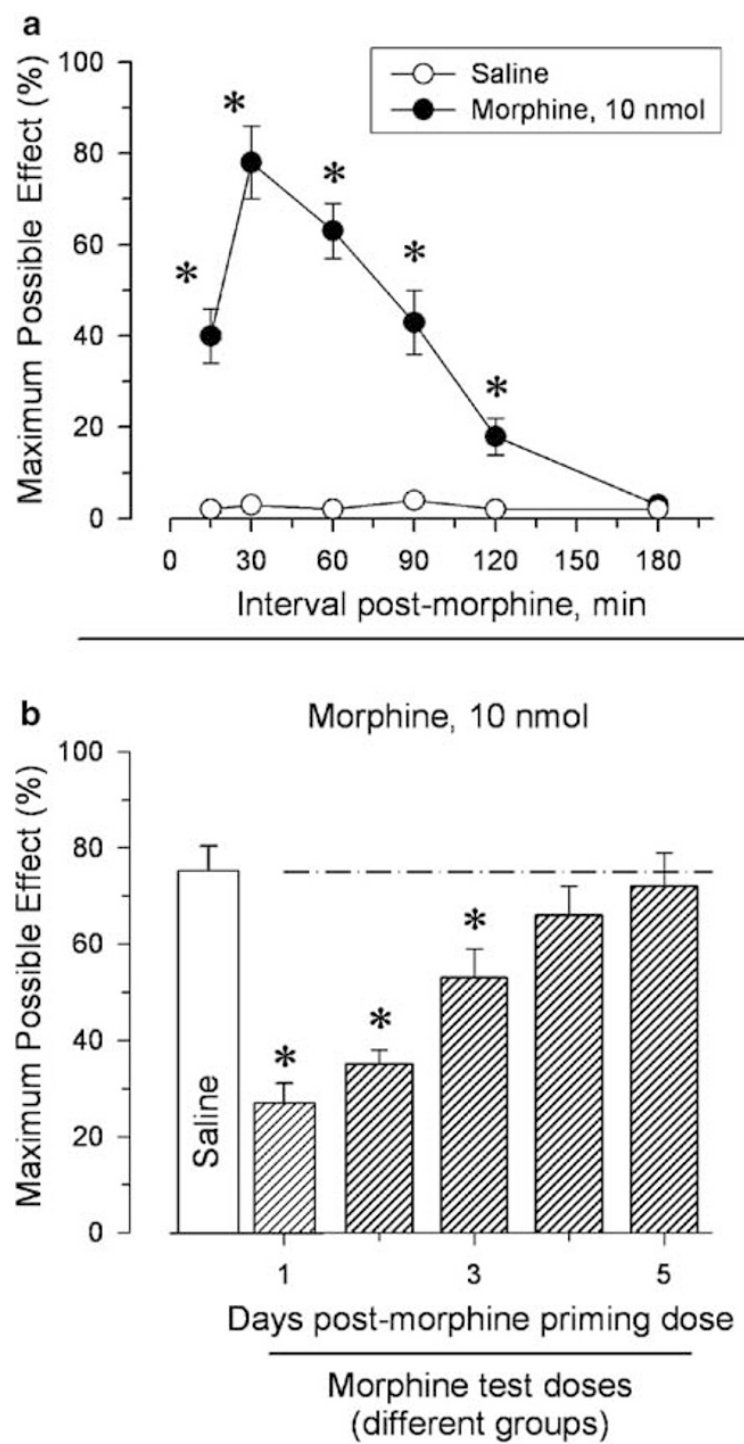

Figure 3 Morphine analgesia and induction of acute tolerance. (a) Time course of $10 \mathrm{nmol}$ morphine-evoked analgesia. Mice were i.c.v. injected with morphine and analgesia determined at various intervals by the warm water $52^{\circ} \mathrm{C}$ tail-flick test. *Significantly different from the control group that received saline instead of the opioid. ANOVA followed by StudentNewman-Keuls test; $p<0.05$. (b) Morphine-induced acute tolerance: A priming dose of $10 \mathrm{nmol}$ morphine or saline (control) was i.c.v. injected into different groups of mice. At $24 \mathrm{~h}$ intervals, parallel groups of morphine priming dose- and saline-treated mice were i.c.v. injected with test doses of $10 \mathrm{nmol}$ morphine, and analgesia evaluated 30 min later by the tail-flick test. Values are mean \pm SEM from groups of 10 to 15 mice. *Significantly different from the analgesic effect of the morphine test dose in mice that had received saline instead of the morphine priming dose (dashed line). ANOVA followed by Student-Newman-Keuls test; $p<0.05$.

reached the predetermined cutoff time of $10 \mathrm{~s}$. Later, they developed a rapid tolerance, and this effect became almost absent at $24 \mathrm{~h}$ (Garzón and Sánchez-Blázquez 2001). In these animals, tolerance to the continuously delivered opioid was monitored measuring the analgesic efficacy of $10 \mathrm{nmol}$ i.c.v. morphine (Figure 6). In naïve mice, this dose of the opioid produced a peak effect of about $80 \%$ of the MPE (Figure 3a). Using this protocol, it was observed that, on days 2 and 3 after pellet implantation, this dose of morphine produced modest antinociceptive effects. On the 
Acute i.c.v. $10 \mathrm{nmol}$ morphine
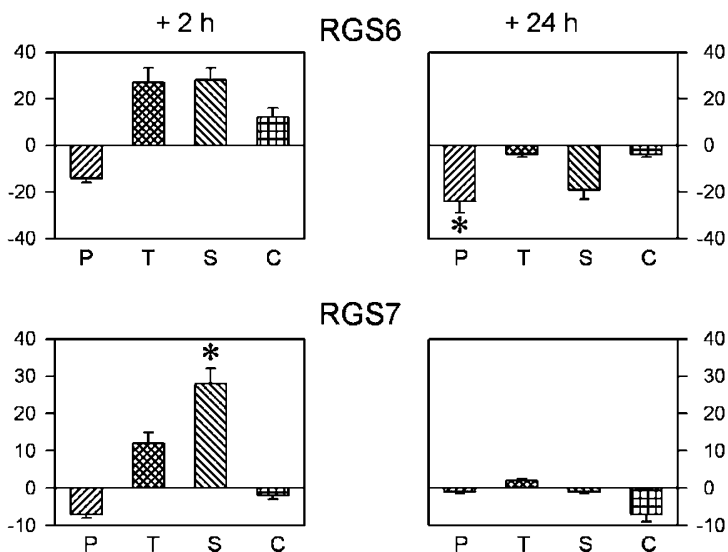

RGS7

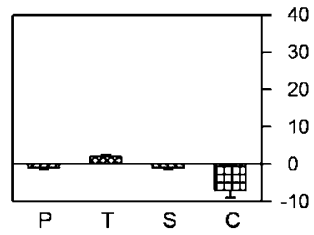

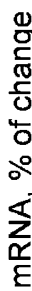

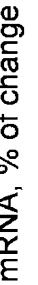

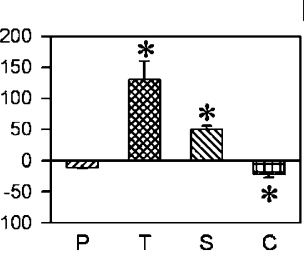

RGS9-2

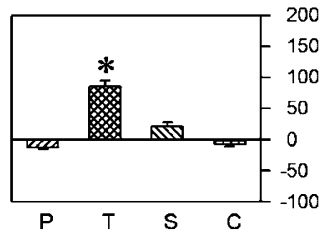

RGS11
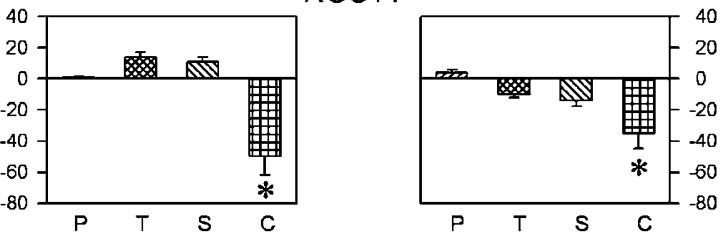

G $\beta 5$
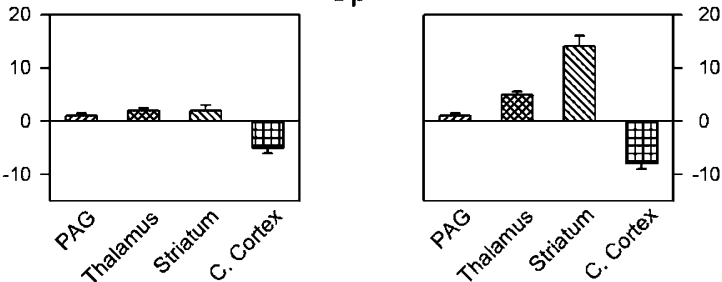

Figure 4 Influence of the development of acute tolerance to morphine on RGS-R7 and G $\beta 5$ mRNA content in neural structures of mouse brain. The mice received i.c.v. injections of $10 \mathrm{nmol}$ morphine or saline (control). At 2 or $24 \mathrm{~h}$ later, they were killed and the neural areas removed. The RTPCR amplified products associated with RGS-R7 and G $\beta 5$ mRNA were normalized with those obtained by amplification of the GAPDH internal standard. For every RGS-R7 and G $\beta 5$, the mRNA data obtained in morphine-treated mice are expressed as a percentage of variation with respect to the results for saline-treated group (control). P (PAG), T (thalamus), S (striatum), and C (cerebral cortex). The structures of at least three mice were pooled for every determination. Each value is the mean \pm SEM of three independent determinations. *Significantly different to the control group. ANOVA followed by Student-Newman-Keuls test; $p<0.05$.

days that followed, its potency started to recover, and about 10 days after pellet implantation the effect of i.c.v. morphine was completely restored (Figure 6).

The jumping behavior precipitated by the opioid antagonist naloxone $(1 \mathrm{mg} / \mathrm{kg}$, s.c.) provided an index of the physical dependence on morphine. During the first 3 days after pellet implantation, the mice exhibited this withdrawal sign upon naloxone challenge. On the 4th day,

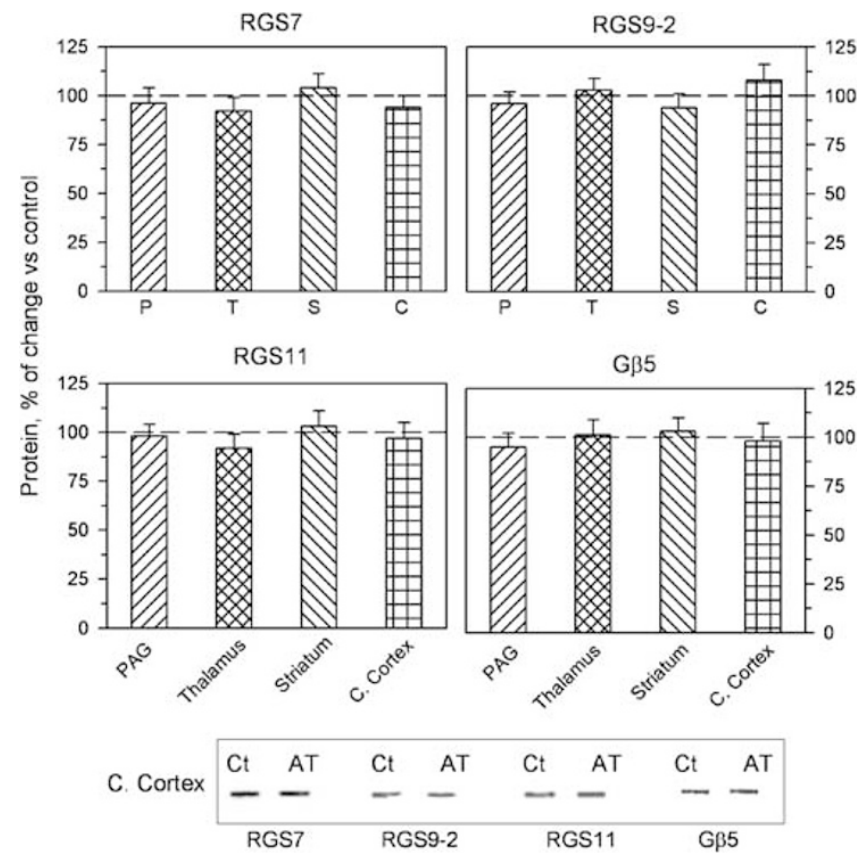

Figure 5 Influence of the development of morphine acute tolerance on RGS-R7 and G $\beta 5$ protein content in neural structures of mouse brain. Immunodetection of RGS proteins and the partner protein $\mathrm{G} \beta 5$ in several CNS structures $24 \mathrm{~h}$ after they had received an i.c.v. injection of $10 \mathrm{nmol}$ morphine. $P$ (PAG), $T$ (thalamus), S (striatum), and $C$ (cerebral cortex). Each value is the mean \pm SEM of three independent determinations. No significant differences were observed between the morphine-treated group and the control that received saline. Inset: representative immunosignals obtained from membranes of cerebral cortex, Ct (control group), AT (morphine acute tolerant group). Details as in the legend to Figure 4.

its intensity started to diminish; on day 8 , this behavior was greatly diminished (Figure 6). The opioid reaches its highest levels in the brain and serum during the first $24 \mathrm{~h}$ after pellet implantation. Later, a sustained reduction takes place, and on the 7th day morphine content is close to the detection threshold offered by the RIA procedure (Garzón and Sánchez-Blázquez, 2001). Thus, after 6 or 7 days, the opioid from the oily pellet appears to be exhausted or prevented from reaching the blood and CNS. At this stage, the morphine tolerant-dependent mice slowly recover their initial response to the opioid. They are then considered post-dependent.

During the $24 \mathrm{~h}$ that followed the implantation of the oily morphine pellet, RGS6, RGS7, RGS9-2, RGS11, and G 35 mRNA levels showed no significant changes in the neural areas analyzed. Later, the corresponding genes reacted to the chronic morphine treatment. During the post-dependent phase, RGS6 mRNA showed decreases of about 40$50 \%$ in the striatum and PAG (Figure 7). The other RGS-R7 members and $G \beta 5$ all showed region-specific increases in their mRNA content. RGS7 mRNA increased moderately (about $30-60 \%$ ) in the PAG, thalamus and cortex of tolerant-dependent mice (2 days). In the post-dependent interval (from day 8 ), these increases persisted in the PAG and cortex, and were also increased in the striatum (Figure 7). In tolerant-dependent mice, the brain levels of RGS9-2 mRNA greatly increased in the PAG (200\%) and thalamus $(500 \%)$ (Figure 8$)$. The changes in these two structures persisted during the post-dependent period. 


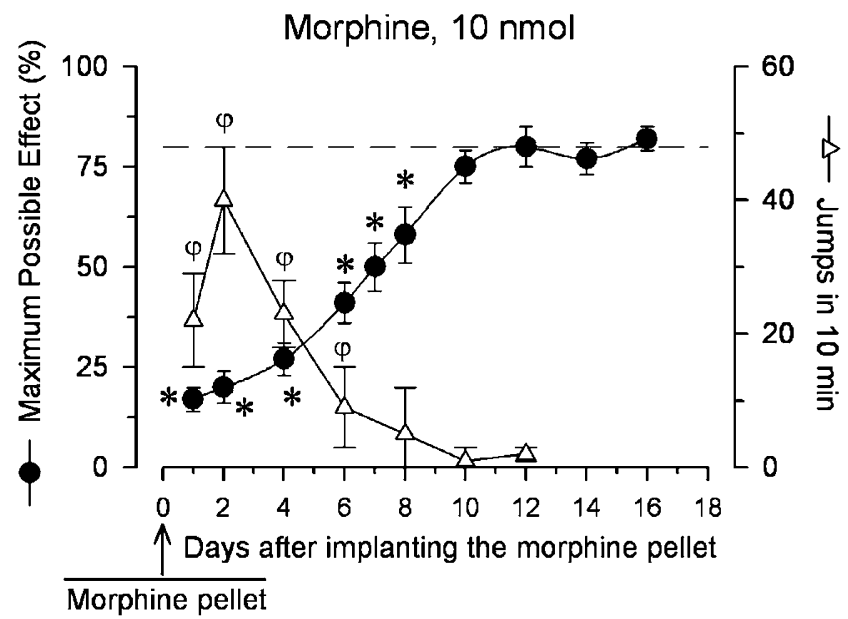

Figure 6 Development of tolerance to sustained chronic morphine. Animals s.c. injected at time zero with a $10 \mathrm{ml} / \mathrm{kg}$ body weight of a suspension containing $50 \%$ saline, $42.5 \%$ mineral oil, $7.5 \%$ mannide monooleate, and $0.1 \mathrm{~g} / \mathrm{ml}$ morphine base developed rapid tolerance to the analgesia promoted by the morphine released from the suspension. The effect was absent $24 \mathrm{~h}$ later. The mice implanted with the morphine oily pellet were divided into several groups and the development of tolerance to morphine monitored by measuring the analgesic response $30 \mathrm{~min}$ after a single i.c.v. dose of $10 \mathrm{nmol}$ morphine. To prevent interference caused by tolerance after receiving a single dose of the opioid, a different group of mice was used to evaluate the effect of i.c.v. morphine at every interval after implantation of the pellet. Thus, each mouse received the morphine suspension s.c. and only one i.c.v. injection of the opioid. In mice not previously exposed to the opioid, $10 \mathrm{nmol}$ morphine produced an effect of about 80\% MPE in the tail-flick test - indicated by the dashed line. The onset and disappearance of physical dependence on morphine was evaluated at different intervals by the jumping behavior that naloxone precipitates in tolerant-dependent mice. To precipitate the withdrawal syndrome, groups of mice implanted with the oily morphine pellet were s.c. injected with I mg/kg of naloxone. Jumps were recorded over the 10 min period following this challenge. The average number of jumps, mean \pm SEM, is shown. Groups of 14-18 mice were used. ${ }^{*} \varphi$ Significantly different to control groups implanted with no oily morphine suspension. ANOVA followed by Student-Newman-Keuls test; $p<0.05$.

Increases of RGS9-2 mRNA in the striatum were also detected at these times, although no significant alteration was seen in the levels of this mRNA in the cortex. The RGS11 mRNA increased in the PAG, thalamus, striatum, and cortex. The greatest increases were of about $80-90 \%$, and appeared during the days the animals were tolerantdependent on morphine. During the post-dependent state, they persisted in the PAG and striatum (Figure 8). Finally, G $\beta 5$ mRNA levels increased by $60-90 \%$ in the PAG, striatum, and cerebral cortex of morphine tolerantdependent mice. No significant changes were observed in the thalamus. The increases in the striatum and cortex were present 8 days after initiating the morphine chronic challenge and beyond 16 days in the PAG (about $30 \%$ ) (Figure 9).

Western blots revealed region-specific increases on the expression of the RGS-R7 and G $\beta 5$ proteins (Figure 10). During the tolerance- and post-dependent phase, the levels of RGS7 protein increased moderately in the thalamus striatum and PAG (50\%) and substantially in the cortex (2- to 2.5-fold) (Figure 7). In addition, although no changes were observed in the cortex, the RGS9-2 protein increased

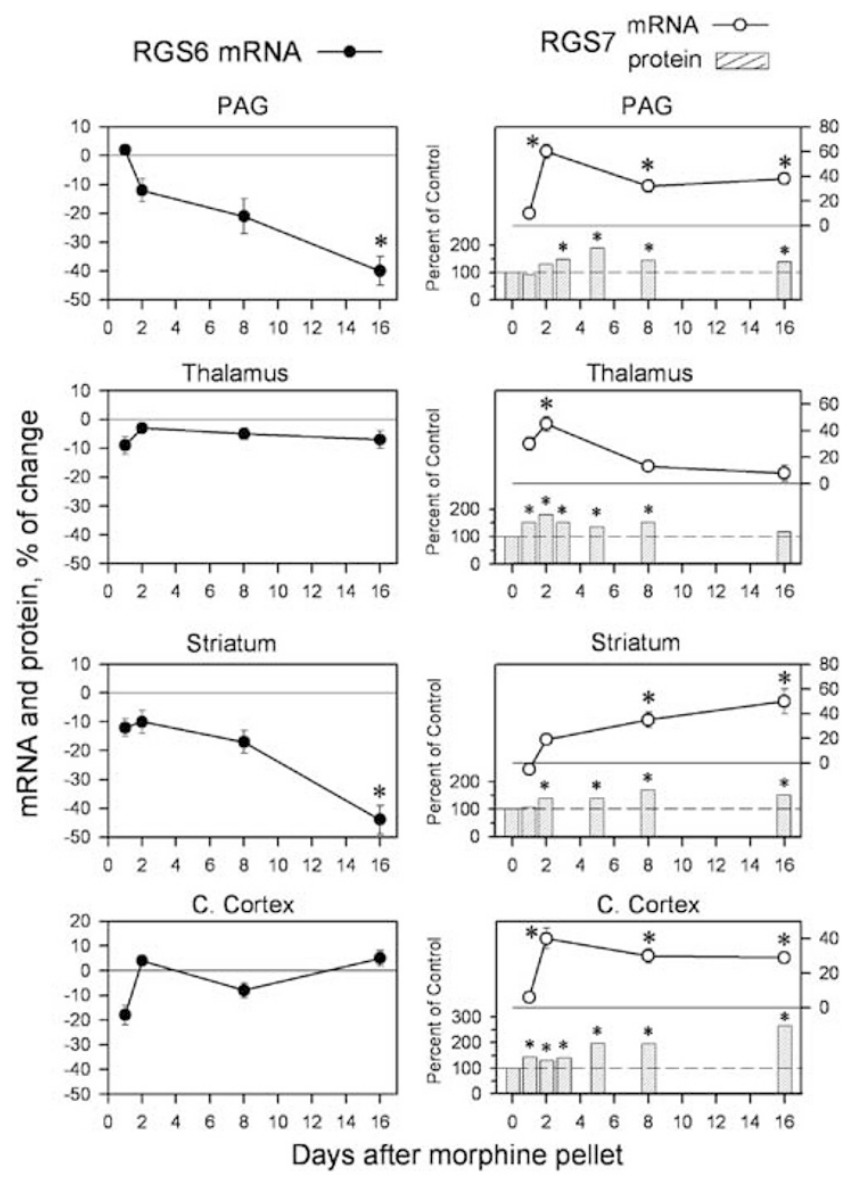

Figure 7 RGS6 and RGS7 mRNA and protein content in brain areas of morphine tolerant- and post-dependent mice. The mice s.c. implanted with the oily morphine suspension were killed at different intervals and their brain structures removed. After performing RT-PCR, the magnitudes of the amplified products, normalized with the GAPDH internal standard, were determined for every interval as the percentage variation with respect to results for the control group. Immunosignals of the expressed RGS proteins are shown at the indicated intervals postimplantation of the oily morphine pellet. The bars show the percentage variation with respect to the control group that received no chronic morphine. *Significantly different to control brain structures from mice implanted with no oily morphine suspension. ANOVA followed by Student-Newman-Keuls test; $p<0.05$.

2- to 3-fold in the PAG, striatum, and thalamus. RGS11 protein content increased about 1.5 -fold in these neural structures (Figure 8). The partner $\mathrm{G} \beta 5$ protein increased 1.5- to 2-fold in all the brain areas studied (Figure 9). Thus, the increases in RGS-R7 and G $\beta 5$ mRNA promoted by chronic morphine exposure reasonably paralleled the increased levels of the proteins they encode.

\section{DISCUSSION}

RT-PCR is the most sensitive technique currently available for mRNA detection and permits quantification of low levels mRNA. This approach therefore allows the detection of mRNA coding for the RGS proteins of the R7 subfamily, of the associated protein G $\beta 5$ (Garzón et al, 2001; SánchezBlázquez et al, 2003; present work), and of the RGS-Rz members GAIP and RGSZ1 in several areas of the mouse brain (Garzón et al, 2004). The present results indicate that 


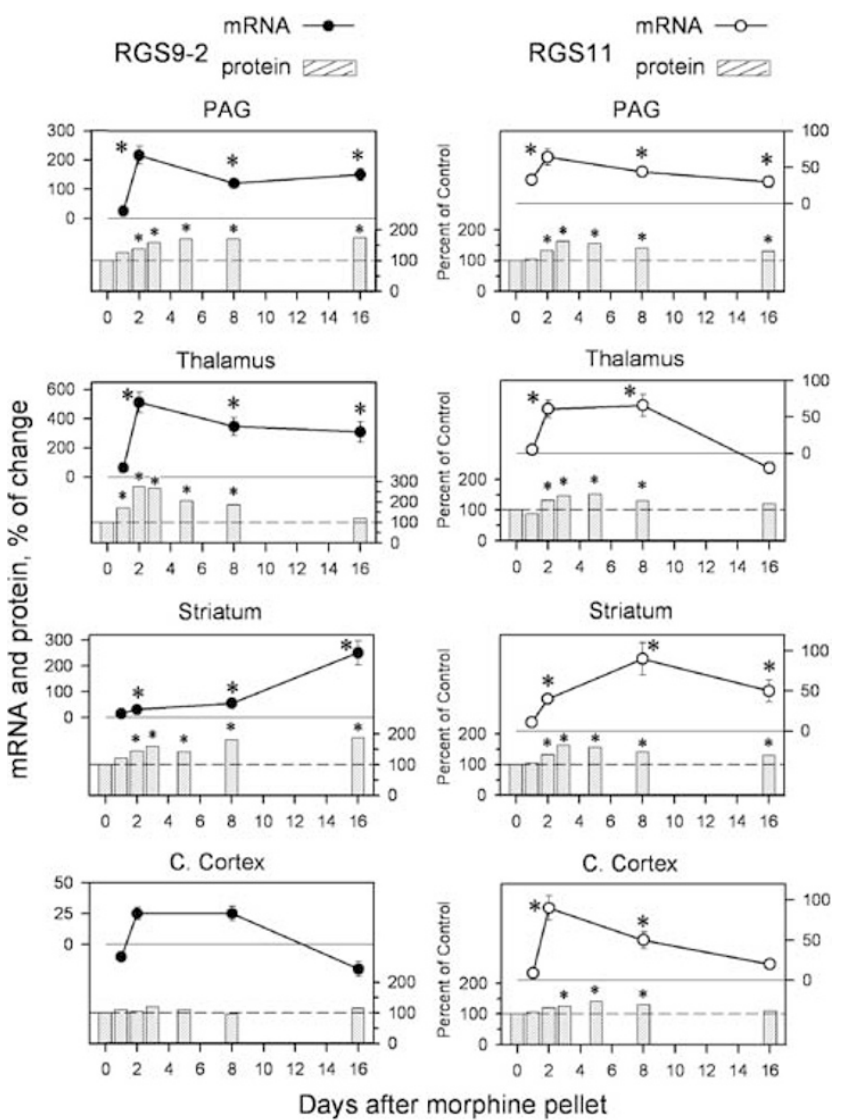

Figure 8 RGS9-2 and RGSII mRNA and protein content in brain areas of morphine tolerant- and post-dependent mice. Experimental details as in the legend to Figure 7.

the RGS-R7 subfamily, although widely expressed in the nervous system of the mouse, shows some region preferences. The highest levels of RGS6 mRNA were found in the spinal cord and pons-medulla, and the lowest in the cerebellum. In situ hybridization studies have revealed a concurrent distribution of this mRNA in rat brain, with levels in the thalamus of this species apparently higher than in the mouse (Gold et al, 1997). The distribution of the murine RGS7 mRNA, the highest levels of which were found in the cerebellum and spinal cord, compares satisfactorily with that reported in in situ hybridization studies on rat brain sections (Gold et al, 1997; Shuey et al, 1998), and also with that obtained by Northern blot analysis (Saitoh et al, 1999).

In the rat, RGS9-2 mRNA is highly expressed in the striatum. Lower levels are also found in the hypothalamus (Gold et al, 1997) and cerebral cortex (Rahman et al, 1999). Recently, Zachariou et al (2003) revealed the existence of RGS9-2 mRNA in rat PAG and spinal cord. In this species, the high levels of RGS9-2 protein expression in the striatum made its detection difficult in other areas of the CNS (Rahman et al, 1999; Zachariou et al, 2003). Using RT-PCR with mouse CNS as the substrate, we confirmed the highest levels of RGS9-2 mRNA to be in the striatum, cortex, and PAG (Garzón et al, 2001). The present results show that RGS9-2 mRNA is most strongly expressed in the striatum, followed by the PAG and hypothalamus. All remaining areas contained less than one-third that seen in the striatum. Therefore, compared to the rat, in the mouse the expression
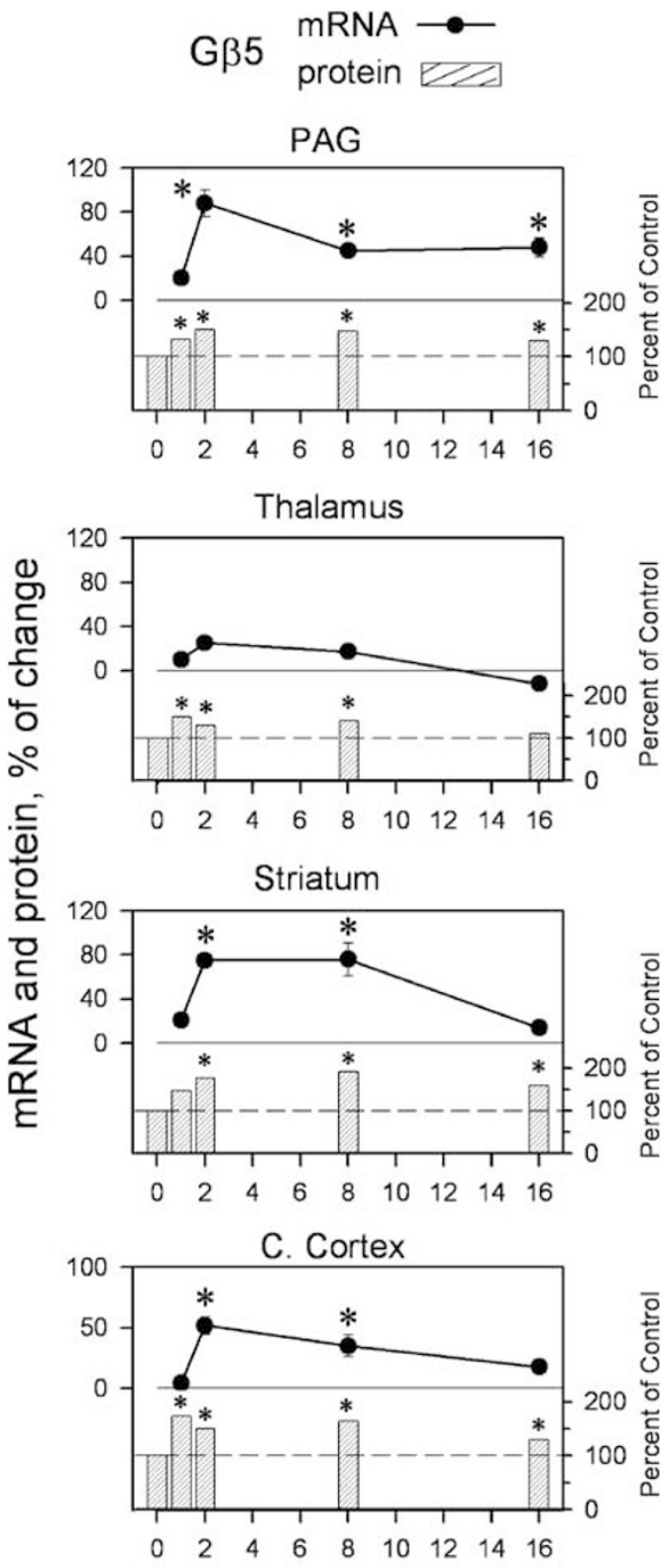

Days after morphine pellet

Figure $9 \mathrm{G} \beta 5 \mathrm{mRNA}$ in brain areas of morphine tolerant- and postdependent mice. Experimental details as in the legend to Figure 7.

of RGS9-2 messenger is less restricted to the striatum. The results also show RGS11 mRNA to be unevenly distributed in the CNS, with relatively high levels in the hypothalamus and PAG, and low levels in the striatum, cerebellum, and spinal cord. Northern blot analyses show an ample distribution for RGS11 mRNA in the human brain (Snow et al, 1998), while in the rat, low levels and a limited distribution are reported (Gold et al, 1997). The mRNA of the RGS-R7-binding protein $\mathrm{G} \beta 5$ is reported to be present in the neural areas evaluated (Sánchez-Blázquez et al, 2003). The highest levels correspond to the hypothalamus, followed by those of the thalamus, PAG, pons-medulla, and cerebellum, which are all similar. The $\mathrm{G} \beta 5$ protein is mostly found associated with neural membranes (Watson et al, 1996; Betty et al, 1998; Sánchez-Blázquez et al, 2003). 


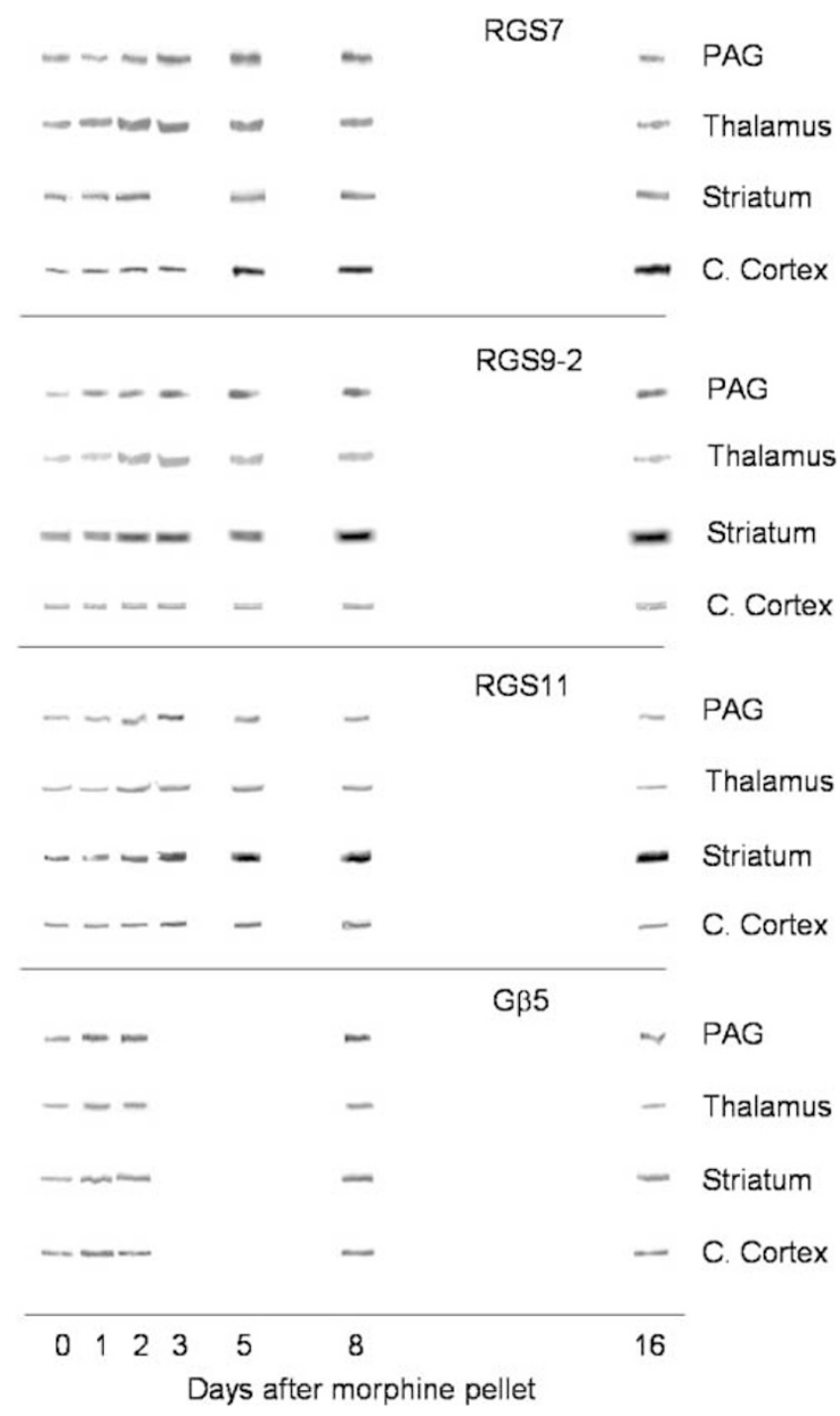

Figure 10 Expression of RGS-R7 and G 35 proteins in areas of mouse brain in morphine tolerant- and in post-dependent mice. The mice received a s.c. morphine oily pellet at time 0 . Groups of mice were killed at the intervals indicated and immunoreactivity was monitored in synaptosomal fractions obtained from the neural areas indicated.

The expression profile observed for these RGS proteins in the mouse brain suggests that they modulate signals originating at a wide variety of G-protein-coupled receptors, including those regulating the transmission of nociceptive stimuli in PAG, thalamus, and spinal cord. In the CNS, the actions of morphine are mediated by $\mu$-opioid receptors (Matthes et al, 1996). The levels of mRNA corresponding to these receptors are enriched in the thalamus, striatum, septum, cortex, and PAG. Lower levels are found in the hypothalamus, nucleus raphe, coliculli, locus coeruleus, pontine and medullary reticular nuclei, dorsal spinal horn, and the lowest in the cerebellum (Mansour et al, 1994; Brodsky et al, 1995a). Thus, the members of the RGS-R7 subfamily are present in those CNS areas where $\mu$-opioid receptors are expressed and participate in the regulation of $\mu$-mediated effects. In fact, it has been documented that the knockdown of RGS-R7 and G $\beta 5$ proteins reduces opioidinduced tachyphylaxis as well as the development of acute tolerance at $\mu$-opioid receptors (Garzón et al, 2001, 2003;
Sánchez-Blázquez et al, 2003). This has also been observed in RGS9 knockout mice (Zachariou et al, 2003). The PAG plays a major role in mediating the supraspinal analgesia of opioids when given by the i.c.v. route (Yaksh et al, 1976). However, since PAG neurons have projections that reach other brain regions (see, for example, Wang and Wessendorf, 2002), the study of the effect of acute morphine on RGS-R7 and G $\beta 5$ mRNA was extended to other neural structures.

An i.c.v. dose of morphine able to produce acute tolerance in mice brought about moderate changes in RGS-R7 mRNA within the first $2 \mathrm{~h}$ of its action. RGS6 and G $\beta 5$ mRNAs showed no change at 2 or $24 \mathrm{~h}$ after acute morphine challenge. RGS7 mRNA levels increased in the striatum as did those of RGS9-2 in the striatum and thalamus. Reductions were observed in RGS9-2 and RGS11 mRNA in the cortex. These changes were much attenuated $24 \mathrm{~h}$ after the single dose injection of morphine. The alterations of mouse brain RGS-R7 mRNA promoted by i.c.v. acute morphine did not bring about significant changes in the expressed proteins. However, it is possible that changes occurred at the level of particular nuclei. In fact, Zachariou et al (2003) report that $2 \mathrm{~h}$ after s.c. administration of morphine, the levels of RGS9-2 protein increase in the nucleus accumbens and dorsal horn of the murine spinal cord. These areas were not included in our study with i.c.v. acute morphine. Collectively, behavioral and also the mRNA data indicate that brief to moderate activation of $\mu$-opioid receptors triggers the endogenous pull of RGS-R7 proteins to reduce agonist effects, therefore contributing to tachyphylaxis and acute tolerance to opioids with no dramatic changes in the expression of the RGS-R7 or G $\beta 5$ proteins. Acute morphine induced RGS-R7 mRNA changes in the striatum and cortex, areas that are not directly involved in the production of opioid antinociceptive effects via the i.c.v. route. These changes are probably induced by projections from some $\mu$-receptor-expressing periventricular neurons that could reach these regions and activate other receptors linked to RGS-R7 regulation.

The sustained morphine treatment brought about regionspecific and time-dependent changes of RGS-R7 and G $\beta 5$ mRNA. The largest increases were those of RGS9-2 in the thalamus $(>500 \%)$ and PAG $(>200 \%)$ in the morphine tolerant-dependent mice. Smaller increases were seen in the striatum. Raised levels of RGS7, RGS11, and G $\beta 5$ mRNA were also observed in most neural structures of these mice. In post-dependent mice, most of the RGS-R7 and G $\beta 5$ mRNA increases persisted 8 to 16 days after starting the chronic opioid treatment. RGS6 mRNA was resistant to change during chronic morphine, but appeared reduced in the PAG and striatum of post-dependent mice. In morphine tolerant-dependent and in post-dependent mice, mRNA changes in brain structures correlated reasonably with increases in RGS-R7 proteins. Zachariou et al (2003) report decreases of RGS9-2 protein levels in the nucleus accumbens and spinal cord in morphine tolerant-dependent mice. These mice were s.c. administered two $25 \mathrm{mg}$ hard morphine pellets on days 1 and 3 , and used for Western blotting assays on day 6 . It is possible that the reductions in RGS9-2 protein are promoted when morphine reaches higher concentrations in the serum and CNS, and for longer intervals than those achieved with the oily suspension. The 
oily pellet provides an animal model of morphine tolerance dependence that retains the rapid rise of morphine in serum described for hard pellets, but which has the benefit of a fast decline of these levels after 4 or 5 days. Thus, their removal is not required to obtain post-dependent animals. This situation is achieved 6 to 8 days after initial delivery of the oily morphine pellet (Garzón and Sánchez-Blázquez, 2001). It should be noted that for a given neural structure, the immunodetected proteins could have originated from local RGS-R7 and G $\beta 5$ mRNA, or have been supplied by projections from other areas of the CNS. Therefore, one should not expect to find the encoded protein restricted to high mRNA content areas. It is therefore feasible that RGS92 proteins originated in areas of high RGS9-2 mRNA expression, for example, the striatum and hypothalamus, are also found in the other CNS structures studied. There are many hypothalamocortical and striatocortical projections (Saper, 1985; Boylan et al, 1986; Hoover and Strick, 1993) that could carry these proteins to the presynaptic side of their axons. It must be remembered that RGS-R7 proteins are associated with $\mathrm{G} \beta 5$ and found in the cell membrane where the regulation of G $\alpha$ GTP subunits takes place (Rose et al, 2000; Zhang and Simonds, 2000; Garzón et al, 2003).

The increases of RGS-R7 mRNA promoted by chronic morphine, accompanied by those of $\mathrm{G} \beta 5 \mathrm{mRNA}$ and protein, are noteworthy. This observation agrees with the proposed coregulation of RGS-R7 and G $\beta 5$ proteins in mammalian cells. However, this balance is not the result of transcriptional regulation. In RGS9-1 knockout mouse retina, the levels of $\mathrm{G} \beta 5$ long splice variant are reduced, although normal amounts of $\mathrm{G} \beta 5$-L mRNA are still present (Chen et al, 2000). Increases in RGS9-1 mRNA by transgenic expression promotes no increase of RGS9-1 protein in the retina (Chen et al, 2003), and $G \beta 5$ knockout mice show reduced or zero levels of RGS-R7 proteins in the retina and striatum (Chen et al, 2003). Therefore, RGS-R7 protein levels are dependent on the coexpression of $\mathrm{G} \beta 5$ and vice versa. The association between RGS7 and G $\beta 5$ to form heterodimers prevents both proteins from being degraded (Witherow et al, 2000). Similar observations have been made for RGS6 and G $\beta 5$ proteins (Snow et al, 1999). The stabilization of these RGS-R7/G $\beta 5$ heterodimers is critical to prevent their rapid degradation by the ubiquitin-dependent proteasome pathway. This could account for the increase of RGS-R7 and G $\beta 5$ proteins observed as a consequence of chronic morphine. However, the reductions in cortical RGS9-2 and RGS11 mRNA observed after acute morphine brought about no reductions of the protein levels. The stabilization of the existing RGS-R7/G $\beta 5$ complexes could delay their downregulation. In fact, treatment intervals longer than $72 \mathrm{~h}$ with antisense oligodeoxynucleotides are required to decrease RGS-R7 and G $\beta 5$ protein levels in mouse brain (Sánchez-Blázquez et al, 2003; Garzón et al, 2001, 2003). Besides RGS-R7 binding to membrane proteins, post-translational modifications such as serine or threonine phosphorylation may impede or delay their degradation (Benzing et al, 1999, 2000; Kim et al, 1999). Thus, phosphorylation and/or binding to $\mathrm{G} \beta 5$ proteins could well preserve these RGS-R7 proteins from being rapidly degraded in the CNS.

Since RGS-R7 proteins play an essential role in the facilitation of acute tolerance at $\mu$-opioid receptors (Garzón et al, 2001, 2003; Sánchez-Blázquez et al, 2003), the increases observed in $\mathrm{RGS}-\mathrm{R} 7 / \mathrm{G} \beta 5$ heterodimers as a consequence of morphine chronic treatment must attenuate the effects of morphine during its chronic action. Further, by reducing the sensitivity of $\mu$ receptors in post-dependent mice, the recovery of the normal function is accelerated. These morphine-induced RGS-R7 and G $\beta 5$ alterations could also affect the function of nonopioid neurotransmitter systems. Of particular interest is the dopaminergic system, which is involved in the rewarding effects of opioids and is also intimately inter-related with RGS-R7 proteins. It is worth noting that in the CNS, acute or chronic morphine treatment produces no alteration of $\mu$-opioid receptor mRNA levels (Brodsky et al, 1995b; Buzas et al, 1996; Castelli et al, 1997). However, dopamine receptor activation does lead to increased levels of $\mu$ receptor mRNA. This is observed in the nucleus accumbens after 3 days of chronic cocaine, SKF 38393, or bromocriptine (Azaryan et al, $1996 \mathrm{a}, \mathrm{b})$. Also, alterations in the abundance of $\mu$ receptor mRNA are observed in dopaminergically innervated brain regions accompanying amphetamine sensitization (Vecchiola et al, 1999; Magendzo and Bustos, 2003). Long-term haloperidol administration or irreversible blockade of D2 dopamine receptors decreases $\mu$ receptor mRNA and protein density in the striatum (Chen et al, 1994; Delfs et al, 1994; Bower et al, 2000). Regulation in the other direction has also been described: chronic morphine exposure and spontaneous withdrawal produce reductions in striatal D1 and D2 dopamine receptor mRNA (Georges et al, 1999). In $\mu$-opioid receptor knockout mice, dopamine receptor D1/D2 mRNA expression is increased in the striatum (Park et al, 2001). This two-way regulation of dopaminergic D1/D2 and $\mu$-opioid receptors, and the responsiveness of RGS-R4 and RGS-R7 mRNA levels to dopaminergic and opioidergic substances (see Introduction and present work), suggests the possibility of dopaminergic control of the facilitatory action of RGS-R7/G $\beta 5$ complexes on $\mu$-opioid tachyphylaxis and acute tolerance. This possibility merits consideration.

In summary, the RGS-R7 and G $\beta 5$ genes showed responsiveness to acute and chronic administration of morphine, although for the neural areas evaluated RGS-R7 protein levels only increased when those of $\mathrm{G} \beta 5$ protein were raised following chronic morphine challenge. The formation of RGS-R7/G $\beta 5$ heterodimers seems to be a requirement for the stabilization of the synthesized proteins, preventing their rapid degradation by the ubiquitin-dependent proteasome pathway. The results of this study further support the regulatory role of RGS-R7 proteins in $\mu$-opioid receptor-mediated effects. Thus, the observed increase in RGS-R7/G $\beta 5$ heterodimers probably helps to attenuate the regulatory pressure that morphine induces on the effectors during its chronic action. By reducing the signaling capacity of the $\mu$-opioid receptors in post-dependent mice, the recovery of the normal responses to the endogenous opioids might be accelerated.

\section{ACKNOWLEDGEMENTS}

This work was supported by the FIS 01/1169, Instituto de Salud Carlos III G03/005, and MCYT BMC2002-03228. 


\section{REFERENCES}

Azaryan AV, Clock BJ, Cox BM (1996a). Mu opioid receptor mRNA in nucleus accumbens is elevated following dopamine receptor activation. Neurochem Res 21: 1411-1415.

Azaryan AV, Coughlin LJ, Búzas B, Clock BJ, Cox BM (1996b). Effect of chronic cocaine treatment on $\mu$ - and $\delta$-opioid receptor mRNA levels in dopaminergically innervated brain regions. J Neurochem 66: 443-448.

Benzing T, Brandes R, Sellin L, Schermer B, Lacker S, Walz G et al (1999). Upregulation of RGS7 may contribute to tumour necrosis factor-induced changes in central nervous function. Nat Med 5: 913-918.

Benzing T, Yaffe MB, Arnould T, Sellin L, Schermer B, Schilling B et al (2000). 14-3-3 interacts with regulator of $G$ protein signaling proteins and modulates their activity. $J$ Biol Chem 275: 28167-28172.

Betty M, Harnish SW, Rhodes KJ, Cockett MI (1998). Distribution of heterotrimeric G-protein $\beta$ and $\gamma$ subunits in the rat brain. Neuroscience 85: 475-486.

Bishop G, Cullinan W, Curran E, Gutstein H (2002). Abused drugs modulate RGS4 mRNA levels in rat brain: comparison between acute drug treatment and a drug challenge after chronic treatment. Neurobiol Dis 10: 334-343.

Bower CM, Hyde TM, Zaka M, Hamid EH, Baca SM, Egan MF (2000). Decreased mu-opioid receptor binding in the globus pallidus of rats treated with chronic haloperidol. Psychopharmacology 150: 260-263.

Boylan MK, Fisher RS, Hull CD, Buchwald NA, Levine MS (1986). Axonal branching of basal forebrain projections to the neocortex: a double-labelling study in the cat. Brain Res 375: $176-181$

Brodsky M, Elliot K, Hynansky A, Jenab S, Inturrisi CE (1995a). Quantitation of mu-opioid receptor (MOR-1) mRNA in selected regions of the rat CNS. Neuroreport 6: 725-729.

Brodsky M, Elliot K, Hynansky A, Jenab S, Inturrisi CE (1995b). CNS levels of mu-opioid receptor (MOR-1) mRNA during chronic treatment with morphine or naltrexone. Brain Res Bull 38: 135-141.

Burchett SA, Bannon MJ, Granneman JG (1999). RGS mRNA expression in rat striatum: modulation by dopamine receptors and effects of repeated amphetamine administration. J Neurochem 72: 15219-15330.

Burchett SA, Volk ML, Bannon MJ, Granneman JG (1998). Regulators of $G$ protein signaling: rapid changes in mRNA abundance in response to amphetamine. J Neurochem 70: 2216-2219.

Buzas B, Rosenberger J, Cox BM (1996). Mu and delta opioid receptor gene expression after chronic treatment with opioid agonist. Neuroreport 7: 1505-1508.

Castelli MP, Melis M, Mameli M, Fadda P, Diaz G, Gessa GL (1997). Chronic morphine and naltrexone fail to modify mu-opioid receptor mRNA in the rat brain. Brain Res Mol Brain Res 45: 149-153.

Chen C-K, Burns ME, He W, Wensel TG, Baylor DA, Simon MI (2000). Slowed recovery of rod photoresponse in mice lacking the GTPase accelerating protein RGS9-1. Nature 403: 557-560.

Chen C-K, Eversole-Cire P, Zhang H, Mancino V, Chen Y-J, He W et al (2003). Instability of GGL domain-containing RGS proteins in mice lacking the $\mathrm{G}$ protein $\beta$-subunit G $\beta 5$. Proc Natl Acad Sci USA 100: 6604-6609.

Chen JF, Aloyo VJ, Qin ZH, Weiss B (1994). Irreversible blockade of D2 dopamine receptor by fluphenazine- $N$-mustard increases D2 dopamine receptor mRNA and proenkephalin mRNA and decreases D1 dopamine receptor mRNA and mu and delta opioid receptors in striatum. Neurochem Int 25: 355-366.

Delfs JM, Yu L, Ellison GD, Reisine T, Chesselet M-F (1994). Regulation of $\mu$-opioid receptor mRNA in rat globus pallidus: effects of enkephalin increases induced by short- and long-term haloperidol administration. J Neurochem 63: 777-780.

Garnier M, Zaratin PF, Ficalora G, Valente M, Fontanella L, Rhee $\mathrm{M}-\mathrm{H}$ et al (2003). Up-regulation of regulator of $\mathrm{G}$ protein signaling 4 expression in a model of neuropathic pain and insensitivity to morphine. J Pharmacol Exp Ther 304: 1299-1306.

Garzón J, López-Fando A, Sánchez-Blázquez P (2003). The R7 subfamily of RGS proteins assists tachyphylaxis and acute tolerance at $\mu$-opioid receptors. Neuropsychopharmacology 28: 1983-1990 (advance online publication, 6 August 2003 (DOI:10.1038/sj.npp.1300263)).

Garzón J, Rodríguez-Díaz M, López-Fando A, García-España A, Sánchez-Blázquez P (2002). Glycosylated phosducin-like protein long regulates opioid receptor function in mouse brain. Neuropharmacology 42: 813-828.

Garzón J, Rodríguez-Muñoz M, López-Fando A, García-España A, Sánchez-Blázquez P (2004). RGSZ1 and GAIP regulate $\mu$-but not $\delta$-opioid receptors in mouse CNS: role in tachyphylaxis and acute tolerance. Neuropsychopharmacology (advance online publication, 3 March 2004 (DOI:10.1038/sj.npp.1300408)).

Garzón J, Rodríguez-Díaz M, López-Fando A, Sánchez-Blázquez P (2001). RGS9 proteins facilitate acute tolerance to mu-opioid effects. Eur J Neurosci 13: 801-811.

Garzón J, Sánchez-Blázquez P (2001). Administration of $\mathrm{myr}^{+}-\mathrm{G}_{\mathrm{i} 2} \alpha$ subunits prevents acute tolerance (tachyphylaxis) to mu-opioid effects in mice. Neuropharmacology 40: 560-569.

Georges F, Stinus L, Bloch B, La Moine C (1999). Chronic morphine exposure and spontaneous withdrawal are associated with modifications of dopamine receptor and neuropeptide gene expression in the rat striatum. Eur J Neurosci 11: 481-490.

Geurts M, Hermans E, Maloteaux J-M (2002). Opposite modulation of regulators of $G$ protein signalling-2 (RGS2) and RGS4 expression by dopamine receptors in the rat striatum. Neurosci Lett 333: 146-150.

Gold SJ, Han M-H, Herman AE, Ni YG, Pudiak CM, Aghajanian GK et al (2003). Regulation of RGS proteins by chronic morphine in rat locus coeruleus. Eur J Neurosci 17: 971-980.

Gold SJ, Heifets BD, Pudiak CM, Potts BW, Nestler EJ (2002). Regulation of regulators of $G$ protein signaling mRNA expression in rat brain by acute and chronic electroconvulsive seizures. J Neurochem 82: 828-838.

Gold SJ, Ni YG, Dohlman HG, Nestler EJ (1997). Regulators of Gprotein signaling (RGS) proteins: region-specific expression of nine subtypes in rat brain. J Neurosci 17: 8024-8037.

Hepler JR (1999). Emerging roles for RGS proteins in cell signalling. Trends Pharmacol Sci 20: 376-382.

Hollinger S, Hepler JR (2002). Cellular regulation of RGS proteins: modulators and integrators of $\mathrm{G}$ protein signaling. Pharmacol Rev 54: 527-559.

Hoover JE, Strick PL (1993). Multiple output channels in the basal ganglia. Science 259: 819-821.

Huidobro F, Huidobro-Toro JP, Way EL (1976). Studies on tolerance development to single doses of morphine in mice. $J$ Pharmacol Exp Ther 198: 318-326.

Huidobro-Toro JP, Way EL (1978). Single-dose tolerance to antinociception, and physical dependence on $\beta$-endorphin in mice. Eur J Pharmacol 52: 179-189.

Kim E, Arnould T, Sellin L, Benzing T, Comella N, Kocher O et al (1999). Interaction between RGS7 and polycystin. Proc Natl Acad Sci USA 96: 6371-6376.

Magendzo K, Bustos G (2003). Expression of amphetamineinduced behavioral sensitization after short- and long-term withdrawal periods: participation of $\mathrm{mu}$ - and delta-opioid receptors. Neuropsychopharmacology 28: 468-477 (advance online publication, 13 September 2002 (DOI:10.1038/ sj.npp.1300063)).

Mansour A, Fox CA, Burke S, Meng F, Thompson RC, Akil H et al (1994). Mu, delta, and kappa opioid receptor mRNA expression 
in the rat CNS: an in situ hybridization study. J Comp Neurol 350: 412-438.

Matthes HW, Maldonado R, Simonin F, Valverde O, Slowe S, Kitchen I et al (1996). Loss of morphine-induced analgesia, reward effect and withdrawal symptoms in mice lacking the mu-opioid-receptor gene. Nature 383: 819-823.

Mirnics K, Middleton FA, Stanwood GD, Lewis DA, Levitt P (2001). Disease-specific changes in regulator of G-protein signaling 4 (RGS4) expression in schizophrenia. Mol Psychiatry 6: 293-301.

Nakagawa T, Minami M, Satoh M (2001). Up-regulation of RGS4 mRNA by opioid receptor agonists in PC12 cells expressing cloned mu- or kappa-opioid receptors. Eur J Pharmacol 433: 29-36.

Ni YG, Gold SJ, Iredale PA, Terwilliger RZ, Duman RS, Nestler EJ (1999). Region-specific regulation of RGS4 (regulator of G-protein-signaling protein type 4) in brain by stress and glucocorticoids: in vivo and in vitro studies. J Neurosci 19: 3674-3680.

Park Y, Ho IK, Fan LW, Loh HH, Ko KH (2001). Region specific increase of dopamine receptor D1/D2 mRNA expression in the brain of mu-opioid receptor knockout mice. Brain Res 894: 311-315.

Potenza MN, Gold SJ, Roby-Shemkowitz A, Lerner MR, Nestler EJ (1999). Effects of regulators of G-protein-signalling proteins on the functional response of the $\mu$-opioid receptor in a melanophore-based assay. J Pharmacol Exp Ther 291: 482-491.

Rahman Z, Gold SJ, Potenza MN, Cowan CW, Ni YG, He W et al (1999). Cloning and characterization of RGS9-2: a striatalenriched alternatively spliced product of the RGS9 gene. J Neurosci 19: 2016-2026.

Rahman Z, Schwarz J, Gold SJ, Zachariou V, Wein MN, Choi K-H et al (2003). RGS9 modulates dopamine signaling in the basal ganglia. Neuron 38: 941-952.

Robinet EA, Geurts M, Maloteaux JM, Pauwels PJ (2001a). Chronic treatment with certain antipsychotic drugs preserves upregulation of RGS2 mRNA in rat striatum as opposed to c-fos mRNA. Neurosci Lett 307: 45-48.

Robinet EA, Wurch T, Pauwels PJ (2001b). Different regulation of RGS2 mRNA by haloperidol and clozapine. Neuroreport 12: 1731-1735.

Rose JJ, Taylor JB, Cockett MI, Jones PG, Hepler JR (2000). RGS7 is palmitoylated and exists as biochemically distinct forms. J Neurochem 75: 2103-2112.

Ross EM, Wilkie TM (2000). GTPase-activating proteins for heterotrimeric $G$ proteins: regulators of $G$ protein signaling (RGS) and RGS-like proteins. Annu Rev Biochem 69: 795-827.

Saitoh O, Kubo Y, Odagiri M, Ichikawa M, Yamagata K, Sekine T (1999). RGS7 and RGS8 differentially accelerate G proteinmediated modulation of $\mathrm{K}^{+}$currents. J Biol Chem 14: 9899-9904.

Sánchez-Blázquez P, García-España A, Garzón J (1995). In vivo injection of oligodeoxynucleotides to $\mathrm{G} \alpha$ subunits and supraspinal analgesia evoked by mu and delta opioid agonists. J Pharmacol Exp Ther 275: 1590-1596.
Sánchez-Blázquez P, García-España A, Garzón J (1997). Antisense oligodeoxynucleotides to opioid $\mathrm{Mu}$ and DELTA receptors reduced morphine dependence in mice: role of DELTA2 opioid receptors. J Pharmacol Exp Ther 280: 1423-1431.

Sánchez-Blázquez P, Rodríguez-Díaz M, López-Fando A, Rodríguez-Muñoz M, Garzón J (2003). The GBeta5 subunit that associates with the R7 subfamily of RGS proteins regulates muopioid effects. Neuropharmacology 45: 85-98.

Saper CB (1985). Organization of cerebral cortical afferent systems in the rat. II. Hypothalamocortical projections. J Comp Neurol 237: 21-46.

Shuey DJ, Betty M, Jones PG, Khawaja XZ, Cockett MI (1998). RGS7 attenuates signal transduction through the G $\alpha \mathrm{q}$ family of heterotrimeric $\mathrm{G}$ proteins in mammalian cells. J Neurochem $\mathbf{7 0}$ 1964-1972.

Snow BE, Betts L, Mangion J, Sondek J, Siderovski DP (1999). Fidelity of $\mathrm{G}$ protein $\beta$-subunit association by the protein $\gamma$ subunit-like domains of RGS6, RGS7, and RGS11. Proc Natl Acad Sci USA 96: 6489-6494.

Snow BE, Krumins AM, Brothers GM, Lee S-F, Wall MA, Chung S et al (1998). A G protein $\gamma$ subunit-like domain shared between RGS11 and other RGS proteins specifies binding to G $\beta 5$ subunits. Proc Natl Acad Sci USA 95: 13307-13312.

Taymans J-M, Leysen JE, Langlois X (2003). Striatal gene expression of RGS2 and RGS4 is specifically mediated by dopamine D1 and D2 receptors: clues for RGS2 and RGS4 functions. J Neurochem 84: 1118-1127.

Vecchiola A, Collyer P, Figueroa R, Labarca R, Bustos G, Magendzo $K$ (1999). Differential regulation of mu-opioid receptor mRNA in the nucleus accumbens shell and core accompanying amphetamine behavioral sensitization. Brain Res Mol Brain Res 69: $1-9$.

Wang $\mathrm{H}$, Wessendorf MW (2002). Mu- and delta-opioid receptor mRNAs are expressed in periaqueductal gray neurons projecting to the rostral ventromedial medulla. Neuroscicence 109: 619-634.

Watson AJ, Aragay AM, Slepak VZ, Simon MI (1996). A novel form of the $\mathrm{G}$ protein $\beta$ subunit $\mathrm{G} \beta 5$ is specifically expressed in the vertebrate retina. J Biol Chem 271: 28154-28160.

Witherow DS, Wang Q, Levay K, Cabrera JL, Chen J, Willars GB et al (2000). Complexes of the $G$ protein subunit $G \beta 5$ with the regulators of G protein signaling RGS7 and RGS9. Characterization in native tissues and in transfected cells. J Biol Sci 275: 24872-24880.

Yaksh TL, Yeung JC, Rudy TA (1976). Systematic examination in the rat of brain sites sensitive to the direct application of morphine: observation of differential effects within the periaqueductal gray. Brain Res 114: 83-103.

Zachariou V, Georgescu D, Sanchez N, Rahman Z, DiLeone R, Berton O et al (2003). Essential role for RGS9 in opiate action. Proc Natl Acad Sci USA 100: 13656-13661.

Zhang JH, Simonds WF (2000). Copurification of brain G-protein $\beta 5$ with RGS6 and RGS7. J Neurosci 20: RC59 (1-5). 